\title{
"Better do not touch" and other superstitions concerning melanoma: the cross-sectional web-based survey
}

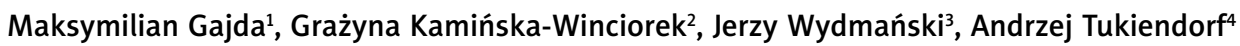 \\ ${ }^{1}$ Clinical Oncology Ward, Starkiewicz Specialised Hospital, Dąbrowa Górnicza, Poland \\ ${ }^{2}$ The Center for Cancer Prevention and Treatment, Katowice, Poland \\ ${ }^{3}$ Department of Conventional and Intraoperative Radiotherapy, Maria Skłodowska-Curie Memorial Cancer Centre and Institute \\ of Oncology Gliwice Branch, Gliwice, Poland \\ ${ }^{4}$ Department of Epidemiology, Maria Skłodowska-Curie Memorial Cancer Centre and Institute of Oncology Gliwice Branch, Gliwice, \\ Poland
}

Adv Dermatol Allergol 2016; XXXIII (5): 329-335

DOI: 10.5114/ada.2016.62837

\begin{abstract}
Introduction: To the authors' best knowledge, there are no data regarding the prevalence of superstitions concerning melanoma among internet users.

Aim: To evaluate the prevalence and identify reasons for superstitions associated with excision of pigmented skin lesions as well as to assess the frequency of this procedure.

Material and methods: Readers of the scientific portal were invited to complete a fully anonymous e-questionnaire. After collection of questionnaires $(5,154)$ and eliminating incomplete ones, 4,919 surveys were analysed.

Results: A total of 4,104 (83.4\%) respondents have been aware that the total surgical excision is the only efficient way of melanoma treatment. This familiarity was related to increased skin cancer awareness but was not linked to regular skin self-examination. Over half of the surveyed agreed that "it is better not to touch naevi". Moreover, 3,510 (71.3\%) individuals believed that naevi located in "harmed places" may turn into melanoma.

Conclusions: Superstitions associated with surgical treatment of melanoma are widespread. Conducting educational campaigns is necessary, particularly among young people, whose dangerous tanning behaviours are important risk factors for melanoma occurrence in their later life.
\end{abstract}

Key words: melanoma, surgery, superstitions, awareness, cross-sectional survey.

\section{Introduction}

Melanoma is the most fatal type of skin cancer. It has been clearly established that exposure to natural or artificial ultraviolet radiation (UVR), typically intermittent or recreational, is the most important known aetiological factor for melanoma development [1-4]. Moreover, the risk of developing melanoma increases with the age, Fitzpatrick phototype scale (higher for light-skinned individuals with pale or red skin pigmentation, bright eye and hair colour) associated with the predisposition for sunburns, number of melanocytic naevi, presence of dysplastic naevi [5-11]. A personal history of other skin cancers as well as a personal or family history of melanoma are other important risk factors for the development of this neoplasm [12-14]. The early stage diagnosis is crucial for more favourable prognosis $[15,16]$. Surgical excision is the primary treatment for an early melanoma [17]. Despite the rapid progress made in the field of melanoma systemic treatment modalities (including new targeted therapies and immunotherapy), the total surgical excision at an early stage of disease remains essential [18, 19]. Nevertheless, superstitions associated with the surgical treatment of this malignancy belong to the most important reasons for seeking medical advice too late, leading to delay in the diagnosis and treatment [20-22]. To the authors' best knowledge, there are no data regarding the prevalence of superstitions concerning melanoma among internet users. In our opinion, this information might be helpful for changing public attitude to skin lesions and improving the results of treatment as proper education could be addressed to groups of high risk.

Address for correspondence: Grażyna Kamińska-Winciorek MD, PhD, The Center for Cancer Prevention and Treatment, 16 Fliegera St, 40-060 Katowice, Poland, fax/cell phone: +48 698626 208, e-mail: dermatolog.pl@gmail.com Received: 26.10.2015, accepted: 1.01.2016. 


\section{Aim}

Therefore, the objective of this study was to evaluate the prevalence of falsehoods among internet users concerning melanoma. Gathering data and subsequent analysis seemed to be necessary in determining the origins of superstitions concerning surgical treatment of melanoma.

\section{Material and methods}

To achieve the study purpose, a dedicated web-based questionnaire was designed and the cross-sectional survey study was conducted among readers of Naukowy.pl, an internet portal dedicated to science.

\section{Basic information about data acquisition}

Acquisition of the respondents' answers was conducted from March to June 2012. To reduce the risk of multiple participation by the same respondent, so-called "cookies" were used, which also allowed the storage of declared consent to participate (or the absence of such approval). Each participant was informed about the purpose and anonymous character of the survey. The self-completion, user-friendly questionnaire was administered in an electronic version, ensuring ease of gathering information and the ability to reach a large number of respondents. The participants answered questions autonomously via a web browser. The Google Docs, freeof-charge platform, was used for preparation and storage of data. After answering all of the required questions, the responses were saved in a spreadsheet. No records were saved that were likely to identify the respondents (e.g. Internet Protocol addresses).

\section{The structure of the questionnaire}

The questionnaire, which was exclusively designed by the authors, contained a total of 61 questions written in Polish that were mainly closed-ended ones (47 questions, Q) as we described previously [23]. Different question subsets were related to demographic data, primary and secondary prevention. The first part of the survey concerned demographic data (age, gender, place of residence, education); the second part queried about characteristics of respondents' behaviours regarding melanoma prevention (occupation, sunbathing, tanning on sunbeds, sunburns, use of sunscreens with ultraviolet A (UVA) and ultraviolet B (UVB)-protective agents, Fitzpatrick phototype, and a family history of melanoma). The final part focused on secondary melanoma prevention.

\section{Ethical issues}

Because of a questionnaire-based character of a study, according to the policy of the Institutional Review Board from the Cancer Centre and Institute of Oncology (Gliwice Branch) the research did not need any approval.

\section{Statistical analysis}

The statistical analysis was conducted on completed questionnaires using the R software [24]. The variables of responses were binomial. They were coded as 0 (negative response; male gender) and 1 (positive response or female gender). Qualitative and quantitative predictors were correlated with binomial responses using the multiple logistic regression. The results were presented classically as odds ratios (OR) and 95\% confidence intervals $(\mathrm{Cl})$. Only statistically significant $(p<0.05)$ results are reported.

\section{Results}

The study group consisted of 4,919 respondents in the mean age of $29.4 \pm 12.8$ (range: 11-92), predominantly female $(N=3,951)$. Majority of them $(74.9 \%)$ declared to live in towns. Nearly a half of the surveyed (47.4\%) declared to have a master's degree or higher.

\section{Public awareness of the total surgical excision as the treatment modality for melanoma}

As many as 4,104 (83.4\%) respondents have been aware that surgery is the only curative treatment modality for melanoma (Q57). These individuals were more often younger, higher educated and were of the opinion that regular tanning increases the risk of melanoma development. Members of this group were more often aware that a history of sunburns could increase the risk of melanoma and knew about its malignancy (Table 1). Although the knowledge about the role of surgery was related to more frequent dermoscopic examinations it did not result in frequent skin self-examination (SSE). People aware of surgery importance significantly less often were of the opinion that "it is better not to touch naevi", however they were more likely to believe in another superstition stating that the naevi located in "often harmed places" could lead to melanoma. Not surprisingly, these respondents significantly more often declared to undergo surgical excision of naevi (Table 1).

\section{Who had surgical treatment of skin lesions?}

A total of 1,406 (28.6\%) respondents declared to ever undergo surgical excision of naevi (Q59). These respondents less often knew that a history of sunburns could increase the risk of melanoma development and declared they did not reapply sunscreens each time after swimming as well as were less likely to divide the skin into phototypes. Moreover, they more often declared having a large number of so-called solar lentigines. They were less likely to perform frequent SSE, however were more likely to seek for advice of a dermatologist and have dermoscopical examination. Despite being aware of the importance of surgery, they significantly more often shared the veracity of both superstitions, while on the other 
Table 1. Knowledge about total surgical excision as melanoma treatment (Q57) and factors related to surgical excision of naevi (Q59)

\begin{tabular}{|c|c|c|}
\hline \multicolumn{3}{|c|}{ Q57 Did you know that the total surgical excision is the only effective way of melanoma's treatment? } \\
\hline Predictors (multivariate) & OR & $95 \% \mathrm{Cl}$ \\
\hline Q1 Your age [years] & $0.9908^{\star * *}$ & $0.9835-0.9981$ \\
\hline Q4 Education - level of schooling completed & $1.2^{*}$ & $1.09-1.32$ \\
\hline Q21 Did you know that regular use of the sun increases the risk of melanoma? & $1.68^{\star *}$ & $1.22-2.31$ \\
\hline Q30 Do you know that a history of sunburns increases the risk of melanoma up to five fold? & $1.7^{*}$ & $1.4-2.07$ \\
\hline Q37 Did you know that melanoma is one of the most malignant cancers? & $2.72^{*}$ & $2.2-3.36$ \\
\hline Q44 Have you ever had a dermoscopic examination performed? & $2.18^{*}$ & $1.58-3$ \\
\hline Q50 Have you ever performed the self-examination of your skin? & $1.39^{\star \star *}$ & $1.08-1.79$ \\
\hline $\begin{array}{l}\text { Q51 Do you regularly observe the skin of the whole body in search of new and old pigmented } \\
\text { moles? }\end{array}$ & $0.9^{\star * \star}$ & $0.83-0.98$ \\
\hline Q55 Do you think that the statement "it is better not to touch naevi" is true? & $0.72^{*}$ & $0.6-0.85$ \\
\hline $\begin{array}{l}\text { Q56 Do you think that the naevi located in "often harmed places" (e.g. belt, bra strap area) } \\
\text { can turn into melanoma? }\end{array}$ & $1.9^{*}$ & $1.6-2.26$ \\
\hline Q59 Have you ever had naevi excised surgically? & $3.07^{*}$ & $2.32-4.07$ \\
\hline \multicolumn{3}{|l|}{ Q59 Have you ever had naevi excised surgically? } \\
\hline Predictor (multivariate) & OR & $95 \% \mathrm{Cl}$ \\
\hline Q15 Do you apply sunscreen cream after each getting out of the water? & $0.83^{* * \star}$ & $0.71-0.97$ \\
\hline Q21 Did you know that regular use of the sun increases the risk of melanoma? & $0.52^{*}$ & $0.36-0.74$ \\
\hline Q30 Do you know that a history of sunburns increases the risk of melanoma up to five fold? & $0.78^{\star \star \star}$ & $0.64-0.96$ \\
\hline $\begin{array}{l}\text { Q33 Can you divide the skin into phototypes depending on the response of skin to sunlight } \\
\text { and sunburn appearance of a tan? }\end{array}$ & $0.82^{\star * \star}$ & $0.69-0.97$ \\
\hline $\begin{array}{l}\text { Q39 Have you ever sought the advice of a dermatologist or other physician specialist for the } \\
\text { evaluation of so-called pigmented moles? }\end{array}$ & $3.05^{*}$ & $2.58-3.6$ \\
\hline $\begin{array}{l}\text { Q41 Do you have a large number of brown sun spots on your back and shoulders - so-called } \\
\text { lentigines? }\end{array}$ & $1.56^{*}$ & $1.32-1.85$ \\
\hline Q44 Have you ever had a dermoscopic examination performed? & $3.4^{*}$ & $2.84-4.08$ \\
\hline $\begin{array}{l}\text { Q51 Do you regularly observe the skin of the whole body in search of new and old pigmented } \\
\text { moles? }\end{array}$ & $0.85^{*}$ & $0.81-0.89$ \\
\hline Q55 Do you think that the statement "it is better not to touch naevi" is true? & $1.76^{*}$ & $1.5-2.07$ \\
\hline $\begin{array}{l}\text { Q56 Do you think that the naevi located in "often harmed places" (e.g. belt, bra strap area) } \\
\text { can turn into melanoma? }\end{array}$ & $2.82^{*}$ & $2.28-3.48$ \\
\hline $\begin{array}{l}\text { Q57 Did you know that the total surgical excision is the only effective way of melanoma's } \\
\text { treatment? }\end{array}$ & $2.77^{*}$ & $2.08-3.67$ \\
\hline $\begin{array}{l}\text { Q58 Would you consider examining your naevi (clinically, dermoscopic examination) after } \\
\text { filling in this questionnaire? }\end{array}$ & $2.7^{*}$ & $2.08-3.52$ \\
\hline
\end{tabular}

hand declared to consider examining their naevi after our survey completion (Table 1).

\section{"It is better not to touch naevi" misconception}

A total of 2,911 (59.2\%) respondents who agreed that "it is better not to touch naevi" (Q55) were more often younger, male and lower educated. Moreover, they less frequently paid attention to the Sun Protection Factor
(SPF) values and slightly less often were able to divide the skin into phototypes as well as to reapply sunscreen. This group of respondents hardly ever sought medical assessment of their moles. The belief in the authority of the statement that naevi located in "often harmed places" can turn into melanoma was also more common in this group. Unfortunately, while having a large number of lentigines, they were less likely to perform SSE, were often 
Table 2. What predisposes to "it is better not to touch naevi" misconception?

\begin{tabular}{|c|c|c|}
\hline \multicolumn{3}{|c|}{ Q55 Do you think that the statement "it is better not to touch naevi" is true? } \\
\hline Predictors (multivariate) & OR & $95 \% \mathrm{Cl}$ \\
\hline Q1 Your age [years] & $0.96^{*}$ & $0.96-0.97$ \\
\hline Q2 Your gender & $0.73^{*}$ & $0.62-0.86$ \\
\hline Q4 Education - level of schooling completed & $0.88^{\star \star}$ & $0.82-0.95$ \\
\hline Q14 How often do you apply sunscreen? & $0.96^{\star \star \star}$ & $0.92-0.99$ \\
\hline Q17 What is the value of SPF used by you? & $0.9951^{* * *}$ & $0.9914-0.9988$ \\
\hline $\begin{array}{l}\text { Q33 Can you divide the skin into phototypes depending on the response of skin to sunlight and } \\
\text { sunburn appearance of a tan? }\end{array}$ & $0.74^{*}$ & $0.65-0.85$ \\
\hline Q37 Did you know that melanoma is one of the most malignant cancers? & $0.76^{\star * *}$ & $0.62-0.92$ \\
\hline $\begin{array}{l}\text { Q39 Have you ever sought the advice of a dermatologist or other physician specialist for the } \\
\text { evaluation of so-called pigmented moles? }\end{array}$ & $0.57^{*}$ & $0.5-0.66$ \\
\hline $\begin{array}{l}\text { Q41 Do you have a large number of brown sun spots on your back and shoulders - so-called } \\
\text { lentigines? }\end{array}$ & $1.48^{*}$ & $1.27-1.71$ \\
\hline $\begin{array}{l}\text { Q51 Do you regularly observe the skin of the whole body in search of new and old pigmented } \\
\text { moles? }\end{array}$ & $0.9^{*}$ & $0.86-0.94$ \\
\hline $\begin{array}{l}\text { Q56 Do you think that the naevi located in "often harmed places" (e.g. belt, bra strap area) can } \\
\text { turn into melanoma? }\end{array}$ & $1.25^{\star *}$ & $1.09-1.45$ \\
\hline $\begin{array}{l}\text { Q57 Did you know that the total surgical excision is the only effective way of melanoma's } \\
\text { treatment? }\end{array}$ & $0.75^{\star *}$ & $0.63-0.89$ \\
\hline $\begin{array}{l}\text { Q58 Would you consider examining your naevi (clinically, dermoscopic examination) after filling } \\
\text { in this questionnaire? }\end{array}$ & $0.85^{\star \star \star}$ & $0.72-1$ \\
\hline Q59 Have you ever had naevi excised surgically? & $1.75^{*}$ & $1.49-2.04$ \\
\hline
\end{tabular}

*Significant at $p<0.001,{ }^{* *}$ significant at $p<0.005,{ }^{* * *}$ significant at $p<0.05$.

unfamiliar with melanoma malignancy and the importance of surgery as well as less often considered examining their naevi after this survey completion (Table 2).

\section{The myth of "often harmed places"}

As many as 3,510 (71.3\%) respondents were of the opinion that naevi located in „often harmed places” (e.g. belt, bra strap area) could turn into melanoma (Q56). They were more likely to be older, more often reapplied sunscreens after swimming as well as paid their attention to the value of UVA-protection factor or anti-UVApersistent pigment darkening (PPD). Unfortunately members of this group were less likely to perform SSE and more often believed in the "better not to touch naevi" misconception while were more likely to have a large number of brown sun spots. Nonetheless, they were likely to undergo dermoscopic examination, be aware of the importance of surgery as a treatment modality for melanoma as well as more often declared to undergo surgical excision of naevi and to be able to divide the skin types according to the Fitzpatrick classification. Moreover, they more often declared to consider examining their naevi after this survey fulfilment (Table 3).

\section{Discussion}

Total surgical excision of skin lesions is one of the most common surgical procedures. Supposed malignancy, aesthetic causes as well as functional disorders were reported to be the main reasons for surgical excision of skin lesions [25]. Understanding that the total surgical excision is the only efficient way of melanoma treatment was quite common (83.4\% of the surveyed) among higher educated respondents and was related to increased skin cancer awareness.

Patients often seek medical advice too late, when the skin lesions seriously raise their concern, which is often accompanied by the presence of symptoms (ulceration, bleeding), which indicate a higher stage of the disease $[22,25,26]$. This is mainly due to the continuous presence of superstitions and low level of knowledge in the field of melanoma [20-23, 25, 26]. The results of our study revealed that the surveyed who underwent surgical excision of any skin lesion were often individuals with a large number of so-called solar lentigines, infrequently obeying safe tanning rules and having fragmentary knowledge in that field. Moreover, they significantly more often shared the veracity of a widespread superstition that a lesion exposed to mechanical irritation could turn into mela- 
Table 3. Analysis of factors concerning the "often harmed places" myth

\begin{tabular}{|c|c|c|}
\hline \multicolumn{3}{|c|}{ Q56 Do you think that the naevi in "often harmed places" (e.g. belt, bra strap) can turn into melanoma? } \\
\hline Predictors (multivariate) & OR & $95 \% \mathrm{Cl}$ \\
\hline Q1 Your age [years] & $1.02^{*}$ & $1.02-1.03$ \\
\hline Q15 Do you apply sunscreen cream after each getting out of the water? & $1.28^{\star \star}$ & $1.11-1.49$ \\
\hline Q17 What is the value of SPF used by you? & $1.0066^{\star *}$ & $1.0023-1.0111$ \\
\hline Q18 Do you choose sunscreen cream based on a UVA-protection factor value or anti-UVA-PPD? & $1.17^{\star \star \star}$ & $1.02-1.35$ \\
\hline $\begin{array}{l}\text { Q33 Can you divide the skin into phototypes depending on the response of skin to sunlight and } \\
\text { sunburn appearance of a tan? }\end{array}$ & $1.22^{\star \star \star}$ & $1.06-1.41$ \\
\hline $\begin{array}{l}\text { Q41 Do you have a large number of brown sun spots on your back and shoulders - so-called } \\
\text { lentigines? }\end{array}$ & $1.37^{*}$ & $1.15-1.64$ \\
\hline Q44 Have you ever had a dermoscopic examination performed? & $1.42^{\star \star}$ & $1.14-1.77$ \\
\hline $\begin{array}{l}\text { Q51 Do you regularly observe the skin of the whole body in search of new and old pigmented } \\
\text { moles? }\end{array}$ & $0.89^{*}$ & $0.85-0.93$ \\
\hline Q55 Do you think that the statement "it is better not to touch naevi" is true? & $1.2^{\star * *}$ & $1.04-1.38$ \\
\hline $\begin{array}{l}\text { Q57 Did you know that the total surgical excision is the only effective way of melanoma's } \\
\text { treatment? }\end{array}$ & $1.99^{*}$ & $1.68-2.35$ \\
\hline $\begin{array}{l}\text { Q58 Would you consider examining your naevi (clinically, dermoscopic examination) after filling in } \\
\text { this questionnaire? }\end{array}$ & $1.75^{*}$ & $1.49-2.05$ \\
\hline Q59 Have you ever had naevi excised surgically? & $3.06^{*}$ & $2.49-3.77$ \\
\hline
\end{tabular}

noma, which could contribute to the decision about surgical treatment. Additionally, there is an old, widespread opinion, ascribed to various types of cancers, that any irritation (e.g. associated with diagnostic biopsies) could induce the spread of metastases [27-30]. The problem whether "cutting into a tumour" could adversely impact the patient's prognosis continues to bother physicians and laymen [31]. Unfortunately, a common belief that it is dangerous to "touch skin changes" is the main cause of seeking the physician advice late. Moreover, it is a source of fear of skin lesion's surgical excision [20-22]. Although incisional biopsies do not affect prognosis, the total surgical excision continues to be the "gold standard" for melanoma surgery and should be favoured as leading to more adequate microstaging of melanoma [17, 31, 32]. This superstition, affecting mainly less aware and younger individuals, is an important factor leading to avoidance of medical assessment as well as is related to infrequent skin self-examination. Our findings linking young age to hazardous tanning behaviours (accompanied by low knowledge about melanoma prophylaxis) are consistent with those previously reported by Gavin et al. denoting a risk factor for skin cancer occurrence in later years [33]. Most of available papers have not established any relationship between single or recurrent/persistent traumatic events and melanoma development $[5,6,8$, $12,13,15,17]$. Only few reports were published supporting such an association $[34,35]$. It seems likely that patients might ascribe melanoma to former trauma incidents, which could facilitate the discovery of this malignancy. Therefore, such an influence is challenging. However, patients with a history of trauma presented with higher thickness of the tumour [36]. In our study, more than a half of the surveyed were of the opinion that lesions in often injured areas of the body might turn into melanoma. It is difficult to elucidate the reason for this situation as these individuals seem to know the rules of safe tanning, skin check-ups, with the exception of infrequent skin self-examination.

There are other common superstitions related to melanoma (not analysed in our study), including prejudice of melanoma inability to grow in body areas not exposed to UV and belief that only people of white skin can suffer from melanoma [37, 38]. As misconceptions about excision of skin lesions and surgical treatment of melanoma are widespread, there is a persistent need for raising awareness through educational campaigns. The effectiveness of this type of activity has been measured by more frequent detection of thin $(0-1 \mathrm{~mm})$ melanomas [39]. In addition to social programs, an individualised approach is also necessary. An earlier assessment of distressing skin lesions can be achieved by having an established dermatologist [39]. Patients have an insufficient level of knowledge of the importance of SSE, regular dermatological check-ups as well as of the need for an early surgical excision of suspicious lesions [40]. Knowledge gained during a dermatology consultation may improve early self-detection of melanoma resulting 
in thinner tumours and more frequent diagnosis of melanoma in situ [41].

The limitations of our study included selection bias (resulting from restricted sampling associated with having an internet access), the need for the sufficient internet skills in order to participate as well as a crosssectional design [42, 43]. Van Gelder et al. concluded that qualitative studies are not prone to selection of participants with different characteristics than the general population (leading to non-response bias) [44]. Participants of our survey were volunteers, so another potential limitation, which is a volunteer bias, should be taken into an account $[43,44]$. The predominance of female respondents may be also associated with their higher interest in the subject. It has been previously demonstrated that women are more likely to participate voluntarily [45]. Taking into account that volunteer participants are more interested in the subject, it can be assumed that the results in a general population could be probably worse than reported.

\section{Conclusions}

Superstitions concerning surgical treatment of pigmented skin lesions are widespread among internet users. Dangerous behaviours related to UVR exposure as well as fairly widespread belief that skin lesions must not be excised are important risk factors for melanoma occurrence in the later life of young people. The continuous education is still required, enabling more frequent diagnosis of changes in a potentially treatable stage. Educational campaigns should be targeted primarily at youth.

\section{Acknowledgments}

The authors are immensely grateful to the study's participants for their engagement.

The name of the department in which the study was conducted, and the name of the department to which the work should be attributed: The Center for Cancer Prevention and Treatment, Fliegera 16, Katowice, Poland, and Department of Conventional and Intraoperative Radiotherapy, Maria Skłodowska-Curie Memorial Cancer Centre and Institute of Oncology Gliwice Branch, Wybrzeże Armii Krajowej 15, Gliwice, Poland.

\section{Conflict of interest}

The authors declare no conflict of interest.

\section{References}

1. Elwood JM, Jopson J. Melanoma and sun exposure: an overview of published studies. Int I Cancer 1997; 73: 198-203.

2. Ting W, Schultz K, Cac NN, et al. Tanning bed exposure increases the risk of malignant melanoma. Int J Dermatol 2007; 46: 1253-7.
3. Armstrong BK, Kricker A. How much melanoma is caused by sun exposure? Melanoma Res 1993; 3: 395-401.

4. Armstrong BK. Epidemiology of malignant melanoma: intermittent or total accumulated exposure to the sun? J Dermatol Surg Oncol 1988; 14: 835-49.

5. Gandini S, Sera F, Cattaruzza MS, et al. Meta-analysis of risk factors for cutaneous melanoma: III. Family history, actinic damage and phenotypic factors. Eur J Cancer 2005; 41: 2040-59.

6. Bliss JM, Ford D, Swerdlow AJ, et al. Risk of cutaneous melanoma associated with pigmentation characteristics and freckling: systematic overview of 10 case-control studies. The International Melanoma Analysis Group (IMAGE). Int J Cancer 1995; 62: 367-76.

7. Jemal A, Devesa SS, Fears TR, Hartge P. Cancer surveillance series: changing patterns of cutaneous malignant melanoma mortality rates among whites in the United States. J Natl Cancer Inst 2000; 92: 811-8.

8. Armstrong BK, Kricker A. The epidemiology of UV induced skin cancer. J Photochem Photobiol B 2001; 63: 8-18.

9. Holly EA, Kelly JW, Shpall SN, Chiu SH. Number of melanocytic naevi as a major risk factor for malignant melanoma. J Am Acad Dermatol 1987; 17: 459-68.

10. Tucker MA, Halpern A, Holly EA, et al. Clinically recognized dysplastic nevi: a central risk factor for cutaneous melanoma. J Am Med Assoc 1997; 277: 1439-44.

11. Nikolaou VA, Sypsa V, Stefanaki I, et al. Risk associations of melanoma in a Southern European population: results of a case/control study. Cancer Causes Control 2008; 19: 671-9.

12. Goggins WB, Tsao H. A population-based analysis of risk factors for a second primary cutaneous melanoma among melanoma survivors. Cancer 2003; 97: 639-43.

13. Florell SR, Boucher KM, Garibotti G, et al. Population-based analysis of prognostic factors and survival in familial melanoma. J Clin Oncol 2005; 23: 7168-77.

14. Goldstein AM, Struewing JP, Fraser MC, et al. Prospective risk of cancer in CDKN2A germline mutation carriers. J Med Genet 2004; 41: 421-5.

15. American Cancer Society. Cancer Facts \& Figures 2013. Available at: http://www.cancer.org/acs/groups/content/@epidemiologysurveilance/documents/document/acspc-036845. pdf [Accessed 04 Jul 2014].

16. Emiroglu N, Cengiz FP, Hofmann-Wellenhof R. Dermoscopic and clinical features of trunk melanomas. Postep Derm Alergol 2014; 31: 362-7.

17. Dummer R, Hauschild A, Guggenheim M, et al. ESMO Guidelines Working Group. Cutaneous melanoma: ESMO Clinical Practice Guidelines for diagnosis, treatment and follow-up. Ann Oncol 2012; 23 Suppl 7: vii86-91.

18. Bedane C, Leccia MT, Sassolas B, et al. French Investigators of the MELODY study. Treatment patterns and outcomes in patients with advanced melanoma in France. Curr Med Res Opin 2013; 29: 1297-305.

19. Olszanski AJ. Current and future roles of targeted therapy and immunotherapy in advanced melanoma. J Manag Care Pharm 2014; 20: 346-56.

20. Schmid-Wendtner MH, Baumert J, Stange J, Volkenandt M. Delay in the diagnosis of cutaneous melanoma: an analysis of 233 patients. Melanoma Res 2002; 12: 389-94.

21. Karabeg R, Lukic D, Janjic $Z$, et al. The analysis of reasons for malignant skin tumors late diagnosis. Mater Sociomed 2012; 24: 73-5. 
22. Gajda M, Kaminska-Winciorek G. Do not let to be late: overview of reasons for melanoma delayed diagnosis. Asian Pac J Cancer Prev 2014; 15: 3873-7.

23. Kamińska-Winciorek G, Gajda M, Wydmański J, Tukiendorf A. What do Web users know about skin self-examination and melanoma symptoms? Asian Pac J Cancer Prev 2015; 16: 3051-6.

24. R Core Team R. A language and environment for statistical computing 2013. R Version 3.0.2. Vienna: R Foundation for Statistical Computing. Available at: http://cran.r-project.org [Accessed 11 Jan 2014].

25. Rissin $\mathrm{Y}$, Fodor $\mathrm{L}$, Ishach $\mathrm{H}$, et al. Patient satisfaction after removal of skin lesions. J Eur Acad Dermatol Venereol 2007; 21: 951-5.

26. Kang JC, Wanek LA, Essner R, et al. Sentinel lymphadenectomy does not increase the incidence of in-transit metastases in primary melanoma. J Clin Oncol 2005; 23: 4764-70.

27. Matsumoto K, Ashizawa K, Tagawa T, Nagayasu T. Chest wall implantation of thymic cancer after computed tomographyguided core needle biopsy. Eur I Cardiothorac Surg 2007; 32: 171-3.

28. Sawabata N, Ohta M, Maeda H. Fine-needle aspiration cytologic technique for lung cancer has a high potential of malignant cell spread through the tract. Chest 2000; 118: 936-9.

29. Davies HE, Musk AW, Lee YC. Prophylactic radiotherapy for pleural puncture sites in mesothelioma: the controversy continues. Curr Opin Pulm Med 2008; 14: 326-30.

30. Fentiman IS, Millis RR, Chaudary MA, et al. Effect of the method of biopsy on the prognosis of and reliability of receptor assays in patients with operable breast cancer. Br J Surg 1986; 73: 610-2.

31. Pflugfelder A, Weide B, Eigentler TK, et al. Incisional biopsy and melanoma prognosis: facts and controversies. Clin Dermatol 2010; 28: 316-8.

32. Karimipour DJ, Schwartz JL, Wang TS, et al. Microstaging accuracy after subtotal incisional biopsy of cutaneous melanoma. J Am Acad Dermatol 2005; 52: 798-802.

33. Gavin A, Boyle R, Donnelly D, et al. Trends in skin cancer knowledge, sun protection practices and behaviours in the Northern Ireland population. Eur J Public Health 2012; 22: 408-12.

34. Zhang N, Wang L, Zhu GN, et al. The association between trauma and melanoma in the Chinese population: a retrospective study. J Eur Acad Dermatol Venereol 2014; 28: 597-603.

35. Ghariani N, Boussofara L, Kenani N, et al. Post traumatic amelanotic subungual melanoma. Dermatol Online J 2008; 14: 13.

36. Kaskel P, Kind P, Sander S, et al. Trauma and melanoma formation: a true association? Br J Dermatol 2000; 143: 749-53.

37. Matzke TJ, Andrew K, Bean AK, Ackerman T. Avoiding delayed diagnosis of malignant melanoma. J Nurse Pract 2009; 5: 42-6.

38. Byrd KM, Wilson DC, Hoyler SS, Peck GL. Advanced presentation of melanoma in African Americans. J Am Acad Dermatol 2004; 50: 21-4.

39. Armstrong A, Powell C, Powell R, et al. Are we seeing the effects of public awareness campaigns? A 10-year analysis of Breslow thickness at presentation of malignant melanoma in the South West of England. J Plast Reconstr Aesthet Surg 2014; 67: 324-30.

40. Czerwinska M, Alekseenko A, Rup E, et al. Retrospective data analysis of the history of patients treated for malignant melanoma at the Department of Dermatology, Jagiellonian
University between 1991 and 2008. Post Dermatol Alergol 2011; 28: 92-6.

41. Cheng MY, Moreau JF, McGuire ST, et al. Melanoma depth in patients with an established dermatologist. J Am Acad Dermatol 2014; 70: 841-6.

42. World Internet Project. Poland 2013. Available at: http:// bi.gazeta.pl/im/5/14910/m14910615,RAPORT-WIP2013.pdf [Accessed 15 Nov 2014].

43. Sedgwick P. Questionnaire surveys: sources of bias. BMJ 2013; 347: f5265.

44. Van Gelder MMHJ, Bretveld RW, Roeleveld N. Web-based questionnaires: The future in epidemiology? Am J Epidemiol 2010; 172: 1292-8.

45. Rosnow R, Rosenthal R. The volunteer subject revisited. Aust J Psychol 1976; 28: 97-108. 